\title{
Communication Behavior of Extension Personnel of State Department of Agriculture of Maharashtra State, India
}

\author{
V.S. Tekale ${ }^{1}$, S.G. Parshuramkar ${ }^{2}$ and S.D. Sarnaik ${ }^{3 *}$ \\ ${ }^{1}$ Department of Extension Education, Dr. PDKV, Akola, India \\ ${ }^{2}$ College of Agriculture, Nagpur, India \\ ${ }^{3}$ Dr. PDKV, Akola (MS) 444 104, India \\ *Corresponding author
}

\section{A B S T R A C T}

\section{Keywords}

Communication behavior, Extension personnel, State department

Article Info

Accepted:

15 June 2019

Available Online:

10 July 2019

The study was conducted in Nagpur district of Maharashtra state. The extension personnel of State Department of Agriculture i.e. agricultural assistants are the grass root functionaries engaged in technology transfer process were the respondents under the present research endeavor. The study sample composed of one hundred agricultural assistants selected by random sampling method from seven taluka of the district. The present investigation aimed to access the overall communication behavior of agricultural assistants as well as to study the relationship between profiles of agricultural assistants with their overall communication behavior. The findings revealed that majority of agriculture assistants $(69.00 \%)$ had observed in medium category of overall communication behavior, while larger section of the respondents i.e. 72.00, 77.00, 44.00, 70.00 and 69.00 per cent were observed in medium category of information seeking, evaluation, processing, transfer and feedback behavior respectively. The variables namely education, gender, service experience, background, training received and facilities available were positively and significantly related with communication behavior of agriculture assistants whereas age of the respondents have shown significant negative correlation.

\section{Introduction}

Collaborative linkage between the 'research system', 'extension system' and 'client system' will proved to be beneficial for the agricultural development process. The knowledge generated by research system disseminated by the extension system towards the farming community (client system). The constant flow of information, knowledge from 'research system' to 'extension system' and there on to farmers is necessary for rapid agricultural development. This flow of information comprises of information acquisition (input), information processing (processing), information dissemination (output) and feedback (response) (Shinde, 1990). 
To have effective transfer of technology among the research system and the farming community, the extension personnel had to play a crucial role. The circle of technology transfer process cannot be completed unless and until effective and efficient role played by an extension personnel. For this purpose the extension personnel ought to be effective information seekers to perform their role as 'facilitators' for accessing farm inputs, advisory services and markets to the farming community.

Grass root extension functionaries are the direct link for bridging the communication gap between the agricultural researchers and the farmers. Under State Department of Agriculture in Maharashtra agricultural assistants had assigned with role of dissemination of information towards farming community. In order to perform this role effectively and efficiently, these agricultural extension personnel must have up to date agricultural information. To achieve meaningful growth in agricultural sector, there is need for a comprehensive and wellarticulated agricultural extension programme which ensures adequate and timely delivery of services to farmers. This research study would provide an insight for studying the communication pattern of extension personnel working state department of agriculture. Accordingly, the present study was planned and conducted in Nagpur district of Maharashtra State with and objective to study the communication behavior of agricultural assistants as well to study the relationship between profiles of agricultural assistants with their communication behavior.

\section{Materials and Methods}

The present study was carried out in purposively selected Nagpur district of Maharashtra state. An exploratory design of social research was used. Nagpur district comprises of 14 Talukas. State Department of Agriculture had 359 sanctioned posts of agricultural assistants in the district. Out of total 14 Talukas seven talukas namely, Umred, Katol, Narkhed, Nagpur, Hingna, Kalmeshwar, and Kamptee were purposively selected for the research endevour and 12, 26, $09,16,16,13$, and 08 agriculture assistants were selected by simple random sampling methods form these talukas, respectively. Thus, 100 Agriculture Assistants were selected and considered as respondents in the present study. For collection of data pretested interview schedule was prepared and data were collected by personally contacting and offering schedule to Agriculture Assistants and filled in schedule by the respondents were collected. The data were tabulated and analyzed by using suitable statistical tools.

\section{Results and Discussion}

\section{Communication behaviour of agriculture assistants}

Rogers (1969) defined communication behaviour as the degree to which an individual is willing to seek information and advice.

Communication behaviour is operationally defined as the expression of result from agricultural information seeking, information evaluation, information processing, information transfer and feedback behaviour of agriculture assistants of State Department of Agriculture in Nagpur district.

\section{Behaviour of agricultural assistants based on different parameters of communication behaviour}

The communication behaviour of agricultural assistants measured on the basis of different parameters of communication behaviour. The five parameters namely, Information Seeking Behaviour, Information Evaluation Behaviour, 
Information Processing Behaviour, Information Transfer Behaviourand Information feedback Behavior of communication was considered to measure the communication behavior of Agriculture Assistants.

The data from Table 1 depicted that, in case of information seeking behaviour majority of respondents had medium level of information seeking behaviour followed by low level (15.00\%). The 13.00 per cent of respondents had high information seeking behaviour. Similarly, majority of the respondents (77.00\%) had medium information evaluation behaviour followed by nearly equal per cent of respondents had high $(12.00 \%)$ and low $(11.00 \%)$. Regarding information processing behaviour higher proportion of the respondents $(44.00 \%)$ had medium level, followed by 39.00 per cent respondents had high level and 17.00 per cent had low level of information processing behaviour. The majority of the respondents had medium $(70.00 \%)$ information transfer behaviour followed by 17.00 and 13.00 per cent had high and low information transfer behaviour. In case of information feedback behaviour majority of the respondents $(69.00 \%)$ had medium level behaviour. Whereas, 23.00 per cent had high and 08.00 per cent had low level information feedback behaviour. By and large all the five selected parameters of communication behaviour had medium level behaviour.

The findings were in conformity with the findings of Bhaltilak (2000).

Table.1 Distribution of respondents based on parameters of communication behaviour

\begin{tabular}{|c|c|c|c|c|c|}
\hline \multirow{2}{*}{$\begin{array}{l}\text { Sr. } \\
\text { No. }\end{array}$} & \multirow[t]{2}{*}{ Parameters } & \multirow[t]{2}{*}{ Categories } & \multicolumn{2}{|c|}{ Respondents $(\mathrm{n}=100)$} & \multirow{2}{*}{$\begin{array}{c}\text { Mean } \\
\text { SD }\end{array}$} \\
\hline & & & Frequency & Percentage & \\
\hline \multirow[t]{3}{*}{1} & \multirow{3}{*}{$\begin{array}{l}\text { Information } \\
\text { seeking } \\
\text { behaviour }\end{array}$} & Low (upto 34.53) & 15 & 15.00 & \multirow{3}{*}{$\begin{array}{l}\text { Mean }=51.47 \\
S D=16.94\end{array}$} \\
\hline & & Medium (34.54 to 68.41$)$ & 72 & 72.00 & \\
\hline & & High (above 68.41) & 13 & 13.00 & \\
\hline \multirow[t]{3}{*}{2} & \multirow{3}{*}{$\begin{array}{l}\text { Information } \\
\text { evaluation } \\
\text { behaviour }\end{array}$} & Low (upto 33.47) & 11 & 11.00 & \multirow{3}{*}{$\begin{array}{l}\text { Mean }=45.78 \\
\mathrm{SD}=12.31\end{array}$} \\
\hline & & Medium (33.48 to 58.09 ) & 77 & 77.00 & \\
\hline & & High (above 58.09) & 12 & 12.00 & \\
\hline \multirow[t]{3}{*}{3} & \multirow{3}{*}{$\begin{array}{l}\text { Information } \\
\text { processing } \\
\text { behaviour }\end{array}$} & Low (upto 43) & 17 & 17.00 & \multirow{3}{*}{$\begin{array}{l}\text { Mean=56.04 } \\
\mathrm{SD}=13.04\end{array}$} \\
\hline & & Medium (43.1 to 69.08 ) & 44 & 44.00 & \\
\hline & & High (above 69.08) & 39 & 39.00 & \\
\hline \multirow[t]{3}{*}{4} & \multirow{3}{*}{$\begin{array}{l}\text { Information } \\
\text { transfer } \\
\text { behaviour }\end{array}$} & Low (upto 32.09) & 13 & 13.00 & \multirow{3}{*}{$\begin{array}{l}\text { Mean }=38.96 \\
S D=6.87\end{array}$} \\
\hline & & Medium (32.10 to 45.83 ) & 70 & 70.00 & \\
\hline & & High (above 45.83) & 17 & 17.00 & \\
\hline \multirow[t]{3}{*}{5} & \multirow{3}{*}{$\begin{array}{l}\text { Information } \\
\text { feedback } \\
\text { behaviour }\end{array}$} & Low (upto 23.88) & 08 & 08.00 & \multirow{3}{*}{$\begin{array}{l}\text { Mean }=36.33 \\
\mathrm{SD}=12.45\end{array}$} \\
\hline & & Medium (23.89 to 48.78$)$ & 69 & 69.00 & \\
\hline & & High (above 48.78) & 23 & 23.00 & \\
\hline
\end{tabular}


Table.2 Distribution of the respondents according to their overall communication behaviour

\begin{tabular}{|c|l|c|c|}
\hline Sr. No. & Category & Frequency $(\mathbf{n = 1 0 0})$ & Percentage (\%) \\
\hline $\mathbf{1}$ & Low (up to 38.71) & 14 & 14.00 \\
\hline $\mathbf{2}$ & Medium (38.72 to 52.73) & 69 & 69.00 \\
\hline $\mathbf{3}$ & High (above 52.73) & 17 & 17.00 \\
\hline & Total & $\mathbf{1 0 0}$ & $\mathbf{1 0 0 . 0 0}$ \\
\hline
\end{tabular}

Mean: $45.72 \quad$ SD: 7.01

Table.3 Correlation between profile of the respondents and their communication behaviour

\begin{tabular}{|c|l|c|}
\hline Sr. No. & Variables & 'r' values \\
\hline $\mathbf{1}$ & Age & $-0.2756^{* *}$ \\
\hline $\mathbf{2}$ & Education & $0.3820^{* *}$ \\
\hline $\mathbf{3}$ & Gender & $0.2919^{* *}$ \\
\hline $\mathbf{4}$ & Service experience & $0.2640^{* *}$ \\
\hline $\mathbf{5}$ & Background & $0.4423^{* *}$ \\
\hline $\mathbf{6}$ & Training received & $0.3451^{* *}$ \\
\hline $\mathbf{7}$ & Facilities available & $0.5734^{* *}$ \\
\hline ** Significant & at 0.01 level of probability & \\
\hline
\end{tabular}

\section{Overall communication behaviour}

The overall communication behavior of the respondents with regard to their information seeking, evaluation, processing, transfer and feedback behaviour were accessed, analyzed and presented in Table 2 .

The perusal of Table 2 revealed that largest proportion of the respondents were observed in medium category of communication behaviour $(69.00 \%)$, followed by 17.00 and 14.00 per cent of the respondents belonged to high and low level of communication behaviour.

The possible reason of medium communication behaviour might be due to medium Information Seeking Behaviour, Information Evaluation Behaviour, Information Processing Behaviour, Information Transfer Behaviour and Information feedback Behavior. The findings were in conformity with the findings of Jahagirdar and Balasubramanya (2008) as duo observed medium level of overall feedback behavior.

\section{Relational analysis}

It was evident from Table 3 that coefficient of correlation between profile of respondents namely, education, gender, service experience, background, training received and facilities available had positive and significant relationship with communication behavior of Agriculture Assistants. Whereas, age shows negative and significant correlation with communication behaviour. As increases in education of Agriculture Assistants they can very effectively communicate to the farmers and their officials, In case of gender it also shows that male respondents were very effectively communicate as they were performing their job at field levels. If the respondents were participated in higher number of training programmes and higher the communication tools/ facilities available to the respondents they can communicate agricultural information very effectively and 
better way the farmers and their officials. But in case of age of respondents, increase in age it decreases their communication behavior this might be due to young Agriculture Assistants they communicate better way and young respondents were very well aware about new communication tools.

The findings were in conformity with the findings of Kumaran et al., (2012).

\section{References}

Bhaltilak Ujwala, 2000, Communication behaviour of anganwadi worker. M.Sc (Agri.) Thesis (Unpub.), Dr. PDKV, Akola.
Jahagirdar K. A. and A.S. Balasubramanya 2008, A Study on Feedback Behaviour of Extension Personnel of Karnataka State Department of Agriculture. Karnataka J. Agric. Sci., 21(1), (89-91).

Kumaran, M., D. D. Vimala, S. Raja and M. Alagappan, 2012, Information Seeking Behaviour of Extension Personnel in Aquaculture Sector, Fishery Technology 49: 87 - 91

Rogers, E.M., 1962, Diffusion of Innovations. The Free Press, New York.

Shinde, P.S., 1990, A study on Communication patterns of research and extension personnel in the $\mathrm{T}$ and $\mathrm{V}$ system of Karnataka state. Ph.D. Thesis, Uni. of Agric. Sci., Dharwad, (India).

\section{How to cite this article:}

Tekale, V.S., S.G. Parshuramkar and Sarnaik, S.D. 2019. Communication Behavior of Extension Personnel of State Department of Agriculture of Maharashtra State, India. Int.J.Curr.Microbiol.App.Sci. 8(07): 1776-1780. doi: https://doi.org/10.20546/ijcmas.2019.807.211 